\title{
Functional Stability Indicators of Organizations Taking into Account the Industry Specifics
}

\author{
Olga B. Gaiman, Alexey A. Sigankov, Olga N. Beketova, Irina V. Shatskaya,
}

\author{
Sergey N. Suslov
}

MIREA - Russian technological university, Moscow, Russia

*Corresponding author. Email: kep2006@mail.ru

\begin{abstract}
The article presents the author's approach to studying the issue of assessing the sustainability of the functioning of light industry organizations for the timely identification of reserves for maximizing financial benefits. The core of such a study was made up of indicators of efficiency and intensification, formed using the computational-constructive method and the method of chain substitutions, related to the traditional indicators for determining the level of success in the implementation of their activities by organizations, adapted to the peculiarities of this sector of the national economy, which is important for humanity in all spheres of its life activity. These features are manifested in the full cycle of business operations of light industry organizations and the movement of the resources they use through three stages of the circulation of capital inherent in material production, in which they function and determine the list of costs associated with its organization, maintenance and sale of products created in it, compared with the proceeds from its implementation. The material is useful for managers and specialists, representatives of science and education in the field of economics and management of light industry and their students.
\end{abstract}

Keywords: organizations, light industry, stability of functioning, efficiency, intensification, result, costs.

\section{INTRODUCTION}

Each sector of the national economy makes a significant contribution to the development of the national economy and the formation of the gross social product and all related indicators that determine the potential and competitiveness of the country and its territorial entities, and therefore shall be resistant to the factors of the internal and external environment. Among them, one of the leading industry positions in terms of consumer demand for created products is occupied by light industry, which is distinguished by its versatility due to its focus on various household and professional spheres of mankind. It ensures the satisfaction of its needs for the necessary manufactured goods required both for the implementation of economic operations and for full-fledged ergonomic comfort, therefore, the organizations employed in it must be resistant to the environment in which they operate. Realizing the relevance of this issue, the authors come to the conclusion about the creation of a toolkit consisting of indicators of the sustainability of the functioning of light industry organizations, focused on their industry specificity by synthesizing general economic works and works of specialized content, and justifying the expediency of their use in analyzing the results of the activities carried out. To translate the author's idea into reality, we will formulate the final and intermediate guidelines (goals and objectives) in the study.

The aim of the study is to form indicators of the sustainability of the functioning of light industry organizations, according to which they can realistically assess the efficiency and intensification of activities and identify the reserves of marginal economic growth. The objectives of the study are to disclose the specifics of their functioning in terms of structuring business stages that affect costs (costs or expenses) and, accordingly, the result (income and profit or proceeds from product sales and profit from sales), by comparing which, light industry organizations will be able to determine to what extent they are stable (effective and intensive) to the 
existing economic environment and perspective when competing in the occupied market segments.

\section{STUDY METHODS}

We will achieve the goal and solve the study tasks through the use of the computational-constructive method and the method of chain substitutions, aimed at detailing the factor indicators that collectively affect the resulting indicators of the sustainability of the functioning of light industry organizations, and intensification. Together, both methods will give an accurate correlation between the efficiency and intensification of the activities of light industry organizations and the desired parametric elements of a relative and absolute nature.

\section{DISCUSSION}

The authors explain the identification of sustainability indicators with indicators of efficiency and intensification of activities by the fact that the first group (indicators of efficiency) refers to the financial condition (profitability), and the second group (indicators of intensification) to changes in the result and costs (changes in profit from sales and costs), then there they reveal the mechanism of economics and management of organizations, without contradicting the sectoral laws of their functioning in the system of economic relations. These postulates are found in general economic works by A.I. Borodin (Borodin, 2013), O.A. Burova (Burova, 2017), L.V. Goloshchapova (Goloshchapova, 2011), S. Yu. Ilyin (Ilyin, 2018; Ilyin, 2019; Ilyin, 2018), A.S. Krasikova (Krasnikova, 2018), I.A. Mandych (Mandych, 2021), G. Ya. Ostaev (Ostaev, 2019), containing the prerequisites for such a classification of the desired indicators. The specificity of the functioning of light industry organizations lies, first of all, in the full cycle of business operations and the movement of resources through three stages of the circulation of capital, since they are part of economic entities in the sphere of material production, which are inherent in the scheme "moneycommodity (M-C) - production $(\mathrm{P})$ - commodity-money $\left(\mathrm{C}^{\prime}-\mathrm{M}^{\prime}\right)^{\prime \prime}$, and it entails the costs of procurement, production and sale of products in the desired industries (textile, clothing, leather, fur, footwear), which is reflected in the publications of M.S. Veretenova (Veretenova, 2008), M.A. Kovtun (Kovtun, 2019), E. D. Korotaeva (Korotaeva, 2020), E.A. Kurnosova (Kurnosova, 2015), A.G. Litvinova (Litvinova, 2014), S.M. Stepanova (Stepanova, 2021), N.Yu. Yaskova (Yaskova, 2018), S.N. Yashin (Yashin, 2007), and serves as a starting point in determining the result of their activities. It is these three groups of costs that are involved in calculating the result from sales of products of light industry organizations. A detailed description of all the above factor indicators of the sustainability of the functioning of light industry organizations is given in Tabl. 1, 2 .

Table 1. Characteristics of the costs of light industry organizations

\begin{tabular}{|l|l|}
\hline \multicolumn{1}{|c|}{ Indicator } & \multicolumn{1}{|c|}{ Content } \\
\hline $\begin{array}{l}\text { The costs of arranging the } \\
\text { textile, sewing, leather, fur, } \\
\text { shoe production (procurement } \\
\text { costs) }\end{array}$ & $\begin{array}{l}\text { Costs of attracting labor } \\
\text { force, means and objects } \\
\text { of labor for the production } \\
\text { of textile clothing, } \\
\text { leather, fur, footwear }\end{array}$ \\
\hline $\begin{array}{l}\text { The costs of running textile, } \\
\text { clothing, leather, fur, footwear } \\
\text { production (technological, } \\
\text { general production and general } \\
\text { business costs) }\end{array}$ & $\begin{array}{l}\text { Costs for the production } \\
\text { of textiles, clothing, } \\
\text { leather, fur, footwear }\end{array}$ \\
\hline $\begin{array}{l}\text { Sales costs of textile, clothing, } \\
\text { leather, fur, footwear } \\
\text { production (selling expenses) }\end{array}$ & $\begin{array}{l}\text { Costs for the sale of } \\
\text { textiles, clothing, leather, } \\
\text { fur, footwear }\end{array}$ \\
\hline
\end{tabular}

Source: author's development

Table 2. Characteristics of the result of light industry organizations

\begin{tabular}{|c|c|}
\hline Indicator & Content \\
\hline $\begin{array}{l}\text { Result (income) from the amount of } \\
\text { expenses for the organization, } \\
\text { maintenance of textile, clothing, } \\
\text { leather, fur, shoe production and the } \\
\text { sale of products obtained in it }\end{array}$ & $\begin{array}{l}\text { Proceeds from the } \\
\text { sale of products of } \\
\text { textile, clothing, } \\
\text { leather, fur, footwear } \\
\text { production }\end{array}$ \\
\hline $\begin{array}{l}\text { Result (economic effect) from the } \\
\text { amount of expenses for the } \\
\text { organization, maintenance of } \\
\text { textile, garment, leather, fur, shoe } \\
\text { production and the sale of products } \\
\text { obtained in it }\end{array}$ & $\begin{array}{l}\text { Profit from sales of } \\
\text { products of textile, } \\
\text { clothing, leather, fur, } \\
\text { footwear production }\end{array}$ \\
\hline
\end{tabular}

Source: author's development

The characteristics of the indicators of the result and costs indicate that they are aligned with the theory of surplus value, therefore, they do not disagree with the principles of calculating efficiency (economic block) and intensification (management block) and, therefore, correspond to the concept of sustainability of functioning of light industry organizations. Hence, the author's indicators for assessing the sustainability of the functioning of organizations in a given branch of the national economy are as follows (formulas (1), (2), (3), (4)): 


$$
\begin{aligned}
& \mathrm{Ef}_{\text {olp }(\mathrm{p})}=\frac{P_{\text {ilp }}}{Z_{\text {oilp }}+Z_{\text {vilp }}+Z_{\text {rilp }}} \\
& \frac{1}{\mathrm{Ef}_{\text {olp }(k a)}+\mathrm{Ef}_{\text {olp }(k b)}+\mathrm{Ef}_{\text {olp }(k c)}},
\end{aligned}
$$

where $\mathrm{Ef}_{\mathrm{olp}(\mathrm{p})}$ is the aggregate direct sustainability or aggregate direct efficiency (direct integral economic indicator) of the functioning of light industry organizations; $\mathrm{P}_{\text {ilp }}$ - profit from sales of light industry products, rubles; $\mathrm{Z}_{\mathrm{oilp}}$ - the costs of organizing production in the light industry, rubles; $Z_{\text {vilp }}$ - costs of production in light industry, rubles; $Z_{\text {rilp }}$ is the cost of selling products manufactured in the light industry, rubles; $\mathrm{Ef}_{\text {olp }}(\mathrm{ka})$ indirect stability of the functioning of light industry organizations in the first group of costs; $\mathrm{Ef}_{\mathrm{olp}}(\mathrm{kb})$ - indirect stability of the functioning of light industry organizations in the second group of costs; $\mathrm{Ef}_{\mathrm{olp}}(\mathrm{kc})$ - indirect sustainability of the functioning of light industry organizations in the third group of costs;

$$
\begin{aligned}
& \mathrm{Ef}_{\text {olp }(\mathrm{k})}=\frac{Z_{\text {oilp }}+Z_{\text {vilp }}+Z_{\text {rilp }}}{P_{\text {ilp }}}=\frac{1}{\operatorname{Ef}_{\text {olp }(p a)}}+\frac{1}{\operatorname{Ef}_{\text {olp }(p b)}}+ \\
& \frac{1}{\mathrm{Ef}_{\text {olp }(p c)}},
\end{aligned}
$$

where $\mathrm{Ef}_{\text {olp (k) }}$ is the aggregate indirect sustainability or aggregate indirect efficiency (indirect integral economic indicator) of the functioning of light industry organizations; $\mathrm{Z}_{\mathrm{oilp}}$ - the costs of organizing production in the light industry, rubles; $Z_{\text {vilp }}$ - costs of production in light industry, rubles; $Z_{\text {rilp }}$ is the cost of selling products manufactured in the light industry, rubles; $\mathrm{P}_{\text {ilp }}$ - profit from sales of light industry products, rubles; $\mathrm{Ef}_{\text {olp (pa) }}$ direct sustainability of the functioning of light industry organizations in the first group of costs; $\mathrm{Ef}_{\mathrm{olp}(\mathrm{pb})}$ - direct sustainability of the functioning of light industry organizations in the second group of costs; $\mathrm{Ef}_{\text {olp }}(\mathrm{ps})$ direct sustainability of the functioning of light industry organizations in the third group of costs;

$$
\begin{aligned}
& \Delta \mathrm{P}_{\mathrm{ilp}}=\left(\frac{1}{\operatorname{Ef}_{\mathrm{olp}(k a) 1}+\mathrm{Ef}_{\text {olp }(k b) 1}+\mathrm{Ef}_{\text {olp }(k c) 1}}-\right. \\
& \left.\frac{1}{\operatorname{Ef}}\right) * \mathrm{SZ}_{\mathrm{olp}(k a) 0}+\mathrm{Ef}_{\mathrm{olp}(k b) 0}+\mathrm{Ef}_{\text {olp }(k c) 0},
\end{aligned}
$$

where $\Delta \mathrm{P}_{\text {ilp }}$ is the change in profit from sales of light industry products due to changes in the total indirect stability or the total direct intensification (direct integral management indicator) of the functioning of its organizations, rubles; $\mathrm{Ef}_{\mathrm{olp}}$ (ka) 1 - reported indirect sustainability of the functioning of light industry organizations for the first group of costs; $\mathrm{Ef}_{\mathrm{olp}}(\mathrm{kb}) 1$ reporting indirect sustainability of the functioning of light industry organizations for the second group of costs; $\mathrm{Ef}_{\text {olp }}$ (kc) 1 - reported indirect sustainability of the functioning of light industry organizations for the third group of costs; $\mathrm{Ef}_{\text {olp (ka) } 0}$ - basic indirect stability of the functioning of light industry organizations in the first group of costs; Ef olp (kb) 0 - basic indirect stability of the functioning of light industry organizations for the second group of costs; Ef olp (kc) 0 - basic indirect stability of the functioning of light industry organizations in the third group of costs; $\mathrm{SZ}_{\mathrm{olp} 1}$ reported total costs of light industry organizations, rubles;

$$
\begin{aligned}
& \Delta \mathrm{SZ}_{\mathrm{olp}}=\left[\left(\frac{1}{\mathrm{Ef}_{\mathrm{olp}(p a) 1}}+\frac{1}{\mathrm{Ef}_{\mathrm{olp}(p b) 1}}+\frac{1}{\mathrm{Ef}_{\mathrm{olp}(p c) 1}}\right)-\right. \\
& \left.\left(\frac{1}{\mathrm{Ef}_{\mathrm{olp}(p a) 0}}+\frac{1}{\mathrm{Ef}_{\mathrm{olp}(p b) 0}}+\frac{1}{\mathrm{Ef}_{\mathrm{olp}(p c) 0}}\right)\right] * \mathrm{P}_{\mathrm{ilp} 1},
\end{aligned}
$$

where $\Delta \mathrm{SZ}_{\text {olp }}$ is the change in the total costs of light industry organizations due to changes in the total direct sustainability or the total indirect intensification (indirect integral management indicator) of the functioning of its organizations, rubles; $\mathrm{Ef}_{\mathrm{olp}(\mathrm{pa}) 1}$ - reporting direct sustainability of the functioning of light industry organizations for the first group of costs; $\mathrm{Ef}_{\mathrm{olp}}(\mathrm{pb}) 1$ reporting direct sustainability of the functioning of light industry organizations for the second group of costs; $\mathrm{Ef}_{\mathrm{olp}}$ (ps) 1 - reporting direct sustainability of the functioning of light industry organizations for the third group of costs; Ef olp (na) 0 - basic straight line stability of functioning of light industry organizations for the first group of costs; $\mathrm{Ef}_{\text {olp }}(\mathrm{pb}) 0$ - basic straight line stability of functioning of light industry organizations for the second group of costs; $\mathrm{Ef}_{\text {olp (pc) } 0}$ - basic straight line stability of functioning of light industry organizations for the third group of costs; $\mathrm{P}_{\mathrm{ilp1} 1}$ - reported profit from sales of light industry products, rubles.

Table 3 shows the interpretation of indicators of the sustainability of the functioning of light industry organizations by economic and management blocks.

The interpretation of economic and management indicators of the sustainability of the functioning of light industry organizations not only does not contradict the generally accepted interpretations of the essence of efficiency and intensification, but also details them in terms of their constituent components, based on the industry specific features considered. Together, they reflect the relationship between the dynamics of the result and costs (direct and indirect intensification) with the dynamics of the effectiveness and cost (direct and indirect efficiency) of the functioning of light industry organizations, thanks to the systematization of the initial indicators (proceeds from the sale of manufactured 
products and calculated costs), built through the selected methods studies that provide for a combination of all types of formalized dependencies, which makes it possible to obtain accurate information about the ranking of the strength of the influence of factor indicators on the resulting indicators and make informed decisions to optimize business processes and financial benefits.

Table 3. Interpretation of indicators of stability of functioning light industry organizations

\begin{tabular}{|c|c|}
\hline Indicator & Content \\
\hline \multicolumn{2}{|c|}{ Economic block } \\
\hline $\begin{array}{l}\text { Aggregate } \\
\text { efficiency of the } \\
\text { functioning } \\
\text { organizations in the } \\
\text { textile, clothing, leather, } \\
\text { fur, footwear industries }\end{array}$ & $\begin{array}{l}\text { Profit from sales of products of } \\
\text { the textile, clothing, leather, } \\
\text { fur, footwear industries per } \\
\text { unit of the amount of their } \\
\text { costs }\end{array}$ \\
\hline $\begin{array}{l}\text { The cumulative indirect } \\
\text { efficiency of the } \\
\text { functioning of } \\
\text { organizations in the } \\
\text { textile, clothing, leather, } \\
\text { fur, footwear industries }\end{array}$ & $\begin{array}{l}\text { The sum of the costs of sold } \\
\text { products of the textile, } \\
\text { clothing, leather, fur, footwear } \\
\text { industries per unit of profit } \\
\text { from their sales }\end{array}$ \\
\hline \multicolumn{2}{|c|}{ Management block } \\
\hline $\begin{array}{l}\text { Aggregate direct } \\
\text { intensification of the } \\
\text { functioning of } \\
\text { organizations in the } \\
\text { textile, clothing, leather, } \\
\text { fur, footwear industries }\end{array}$ & $\begin{array}{l}\text { Change in profit from sales of } \\
\text { products due to changes in the } \\
\text { total indirect sustainability of } \\
\text { the functioning of } \\
\text { organizations in the textile, } \\
\text { clothing, leather, fur, footwear } \\
\text { industries }\end{array}$ \\
\hline $\begin{array}{l}\text { Aggregate indirect } \\
\text { intensification of the } \\
\text { functioning of } \\
\text { organizations in the } \\
\text { textile, clothing, leather, } \\
\text { fur, footwear industries }\end{array}$ & $\begin{array}{l}\text { Change in total costs due to } \\
\text { changes in the total direct } \\
\text { sustainability of the } \\
\text { functioning of organizations in } \\
\text { the textile, clothing, leather, } \\
\text { fur, footwear industries }\end{array}$ \\
\hline
\end{tabular}

\section{CONCLUSION}

The author's approach to understanding the sustainability of the functioning of light industry organizations is justified, since it provides for a symbiosis of general scientific and industry postulates in the formation of its indicators. Calculating their values, light industry organizations will have complete and reliable information about the efficiency and intensification of their activities and will be able to make timely adjustments that contribute to the maximum possible economic development with the most beneficial results and costs, ensuring strong competitive positions in the long term.

\section{REFERENCES}

[1] A.I. Borodin, L.V. Goloshchapova, Economic and mathematical model of enterprise potential formation, Bulletin of the Samara State Aerospace University named after V.I. Academician S.P. Korolev (National Research University), 1(39) (2013) pp. 268-276.

[2] O.A. Burova, Human capital as a factor in the growth of the country's economy and technological renewal of production, Izvestiya vuzov. Textile industry technology, 2 (2017) pp. 19-22.

[3] M.S. Veretenova, E.A. Zaitseva, Trends in the socio-economic development of the light industry of the Russian Federation, Scientific works of the free economic society of Russia, 89 (2008) pp. 34-43.

[4] L.V. Goloshchapova, The essence and content of the economic potential of the enterprise, Bulletin of the University, 22 (2011) pp. 122-124.

[5] S.Yu. Ilyin, Cost indicators of the efficiency of agricultural organizations, Agrarian scientific magazine, 6 (2018) pp. 86-89.

[6] S.Yu. Ilyin, Economy of modern organizations, Transport business of Russia, 4 (2019) pp. 17-18.

[7] M.A. Kovtun, O.V. Saradzheva, Economic security of light industry in Russia, Economy today: current state and development prospects (Vector-2019), 2019, pp. 184-187.

[8] E.D. Korotaeva, Factors affecting the efficiency of light industry enterprises, Tribune of the scientist, 7 (2020) pp. 258-260.

[9] A.S. Krasnikova, Research of problems of interfunctional coordination at industrial enterprises, Bulletin of the Moscow State Regional University. Series: Economics, 4 (2018) pp. 67-74.

[10] E.A. Kurnosova, The main factors of increasing the efficiency of light industry enterprises, Bulletin of the Samara State University. Series: Economics and Management, 9-1(131) (2015) pp. 130-136.

[11] A.G. Litvinova, Analysis of the situation in the Russian light industry, Bulletin of RUDN. Series: Economics, 2 (2014) pp. 16-26.

[12] I.A. Mandych, A.V. Bykova, Difficulties and prospects for the development of high-tech projects in the era of digital transformation of the economy, 
Russian technological magazine, 9(2) (2021) pp. 8895.

[13] G.Ya. Ostaev, G.S. Klychova, V.A. Sokolov, K.Z. Mukhamedzyanov, Development of a financial strategy in management accounting, Bulletin of Kazan State Agrarian University, 14(2(53)) (2019) pp. 170-175.

[14] S. M. Stepanova, L. V. Goloshchapova, S. N. Speransky, N. E. Pakhotin, Integral assessment of the economic potential of an industrial enterprise, News of higher educational institutions. Textile industry technology, 1(391) (2021) pp. 5-10.

[15] N. Yu. Yaskova, I. G. Lukmanova, From competitiveness to the strategic advantage of the enterprise, News of higher educational institutions. Textile industry technology, 2(374) (2018) pp. 4449.

[16] S.N. Yashin, M.S. Salatova. Problems of restoring light industry at the federal and regional levels, Regional economy: theory and practice, 13 (2007) pp. 19-22.

[17] S.Y. Ilyin, Tools for calculating the development indicators of the economy of organizations, International Journal of Civil Engineering and Technology, 9(8) (2018) pp. 1681-1688. 